\title{
Kesulitan Belajar Siswa pada Pembelajaran Daring Matematika di Masa Pandemi
}

\author{
Ervika Ratna Yulia ${ }^{1}$, Ika Wahyuni ${ }^{2}$, Anggita Maharani ${ }^{3}$ \\ ${ }^{1,2}$ Program Studi Pendidikan Matematika, Fakultas Keguruan dan Ilmu Pendidikan Universitas Swadaya Gunung Jati, \\ Jl. Perjuangan No.1, Kota Cirebon \\ ervikaratnayulia.ery@gmail.com
}

\begin{abstract}
Students are one component in learning activities. In the context of developing self-potential, each student has different abilities. So even with the difficulties he faces, will be different. Students always find difficulties in the learning process at school. After the learning process is changed to online, the difficulties that students need to face also increase. Especially in the online learning process in mathematics. Based on this background, the researchers are interested in researching "Students' Learning Difficulties in Mathematics Online Learning in the Pandemic Period". So, the purpose of this study is to find out the difficulties experienced by students during online learning in the hope of finding solutions to these problems. Based on the results of research, learning difficulties experienced by students in online learning mathematics during the pandemic include: (1) Technical constraints that affect signals and disabilities in online learning are constraints on signals and quotas they have, (2) Because students do not like math subjects, do not like teachers who teach mathematics subjects, students only learn mathematics during class hours, in online learning mathematics teachers who teach do not openly question and answer sessions with students, how to teach teachers in online-based mathematics learning is considered unpleasant, (3) There are no stakeholders who help the government, schools and parents in online learning.
\end{abstract}

Keywords: learning difficulties, online learning

\begin{abstract}
Abstrak
Siswa adalah salah satu komponen dalam kegiatan pembelajaran. Setiap siswa memiliki kemampuan yang berbeda-beda dalam hal pengembangan potensi diri. Begitu pun dengan kesulitan yang dihadapinya, akan berbeda pula. Siswa selalu menemukan kesulitan dalam proses pembelajaran di sekolah. Setelah proses pembelajaran diubah menjadi dalam jaringan, kesulitan yang perlu dihadapi oleh siswa juga bertambah. Apalagi dalam proses pembelajaran dalam jaringan pada pelajaran matematika. Berdasarkan latar belakang tersebut maka peneliti tertarik untuk meneliti "Kesulitan Belajar Siswa pada Pembelajaran Daring Matematika di Masa Pandemic". Sehingga tujuan dari penelitian ini adalah ingin menganalisis kesulitan yang dialami siswa selama pembelajaran daring dengan harapan dapat mencari solusi dari permasalahan tersebut. Berdasarkan hasil penelitian kesulitan belajar yang dialami siswa pada pembelajaran daring matematika di masa pandemi di antaranya: (1) kendala pada sinyal dan kuota yang dimiliki, (2) Karena siswa tidak menyukai mata pelajaran matematika dan guru yang mengajar mata pelajaran matematika, siswa hanya belajar matematika pada saat jam pelajarannya saja, dalam pembelajaran daring matematika guru yang mengajar tidak membuka sesi tanya jawab dengan siswa, cara mengajar guru dalam pembelajaran matematika berbasis daring pun dianggap tidak menyenangkan, (3) Belum optimalnya peran stake holder dalam pembelajaran daring.
\end{abstract}

Kata kunci: kesulitan belajar, pembelajaran daring

Copyright (c) 2021 Ervika Ratna Yulia, Ika Wahyuni, Anggita Maharani

$\triangle$ Corresponding author: Ika Wahyuni

Email Address: ik.math84@gmail.com (Jl. Perjuangan No.1, Kota Cirebon)

Received 22 June 2021, Accepted 25 July 2021, Published 25 September 2021

\section{PENDAHULUAN}

Akhir tahun 2019, berdasarkan laporan Cina kepada World Health Organization (WHO), dunia dikagetkan dengan kejadian infeksi berat dengan penyebab yang belum diketahui di Wuhan China (Handayani, D., Hadi, R, D., Isbaniah, F., Burhan, E., \& Agustin, 2020). Wabah penyakit tersebut adalah Coronavirus Diseases 2019 (Covid-19) yaitu virus berbahaya dan mudah menular terhadap sesama 
manusia (Ilpaj, S. M., \& Nurwati, 2020). Sejak penyebaran Covid-19 ini meluas ke Indonesia, angka yang menunjukkan positif corona semakin membludak setiap harinya. Guna mengantisipasi penyebaran yang semakin merajalela, pemerintah melakukan berbagai upaya untuk menekan pertambahan penyebaran covid-19 tersebut. Salah satu upaya yang dilakukan oleh pemerintahan Indonesia adalah dengan melakukan pembatasan sosial skala besar atau PSBB. Dengan disemarakkannya PSBB ini, proses pembelajaran pun pelaksanaannya dirubah, dari yang tadinya belajar di sekolah menjadi belajar di rumah.

Belajar di rumah memiliki berbagai manfaat, diantanya adalah siswa dapat belajar dengan aman dan nyaman di rumah, praktis, dan ekonomis (Utami, Y. P., \& Cahyono, 2020). Walaupun demikian, kegiatan belajar di rumah tetap memiliki kekurangan yang salah satunya adalah kesulitan yang dialami oleh siswa itu sendiri. Setiap kegiatan yang kita lakukan, mustahil sekali apabila tidak ada kesulitan. Akan selalu ada hambatan dan tantangan yang harus kita hadapi dalam menjalani kehidupan. Begitu pun dalam proses balajar mengajar. Berbagai kesulitan dapat kita temukan, terutama dalam belajar di rumah (daring) khususnya pada pelajaran matematika.

Matematika sering dianggap sebagai yang paling sulit. Hal tersebut terjadi karena materi dari pelajaran matematika sendiri yang memang sudah sulit. Apalagi pembelajaran dilakukan secara daring, hasil penelitian yang dilakukan oleh Fauzy dan Nurfauziyah (2021), salah satu kesulitannya adalah banyaknya rumus yang digunakan dalam matematika dan objek yang di pelajari dalam matematika memiliki pola abstrak. Walaupun demikian, setiap orang harus mempelajarinya karena hal tersebut penting sebagai sarana untuk memecahkan masalah kehidupan sehari-hari. Sehingga, siswa dituntut untuk mempelajari (Mutia, 2019).

Kemampuan siswa dalam pengembangan potensi diri sangat beragam. Begitu pun dengan kesulitan yang dihadapinya, akan berbeda pula (Ismail, 2016). Siswa selalu menemukan kesulitan dalam proses pembelajaran di sekolah. Setelah proses pembelajaran diubah menjadi dalam jaringan, kesulitan yang perlu dihadapi oleh siswa juga bertambah. Apalagi dalam proses pembelajaran dalam jaringan pada pelajaran matematika. Sehingga rumusan masalah dalam penelitian ini adalah "Apa saja kesulitan belajar siswa pada pembelajaran daring matematika pada saat pandemi covid-19?"

\section{METODE}

Metode penelitian yang digunakan adalah metode penelitian kualitatif, karena dalam penelitian ini partisipan dijadikan sebagai subjek bukan sebagai objek. Metode penelitian kualitatif juga merupakan metode yang memiliki dua ciri utama yaitu data yang tidak berbentuk angka di mana data dalam penelitian ini lebih banyak dalam bentuk narasi atau deskripsi, dan penelitian ini tidak memiliki rumus atau aturan absolut dalam proses pengolahan datanya (Gumilang, 2016; Raco, Dr. J. R., M.E, 2004).

Jenis metode penelitian yang digunakan adalah penelitian deskriptif dan bersifat penelitian kasus. Metode deskriptif merupakan prosedur pemecahan masalah yang diselidiki dengan melukiskan 
Kesulitan Belajar Siswa pada Pembelajaran Daring Matematika di Masa Pandemi, Ervika Ratna Yulia, Ika Wahyuni, Anggita Maharani

keadaan subjek/objek peneliti pada saat sekarang berdasarkan fakta-fakta yang nampak atau sebagaimana adanya (Ari, I. N., \& Sihombing, 2017).

Subjek penelitian dalam penelitian ini adalah lima orang siswa kelas IV SD Negeri di salah satu daerah Kabupaten Majalengka. Penelitian ini dilaksanakan pada tahun ajaran 2020/2021. Penelitian ini bertempat di Desa Lengkong Wetan Kecamatan Sindangwangi Kabupaten Majalengka karena keterbatasan peneliti dalam meneliti di masa Covid-19.

Teknik pengumpulan data yang digunakan adalah triangulasi data, terdiri atas wawancara, observasi dan dokumentasi. Wawancara merupakan bentuk pengumpulan data yang paling sering digunakan dalam penelitian kualitatif (Rachmawati, 2007). Dalam melakukan wawancara, peneliti menyiapkan instrumen wawancara meliputi 20 pertanyaan tertulis. Pertanyaan yang diberikan kepada responden adalah pertanyaan yang sama.

Dalam penelitian ini, peneliti menggunakan instrumen penelitian berupa lembar wawancara yang terdiri dari 20 pertanyaan tentang kesulitan belajar matematika yang dihadapi siswa pada pembelajaran daring di masa Covid-19.

Terdapat tiga tahapan meliputi tahap persiapan, tahap pelaksanaan di lapangan, dan tahap pasca lapangan (Januarti, N. K., Dibia, I. K., \& Widiana, 2016). Berikut Diagram alir penelitian yang dilakukan disajikan pada Gambar 1.

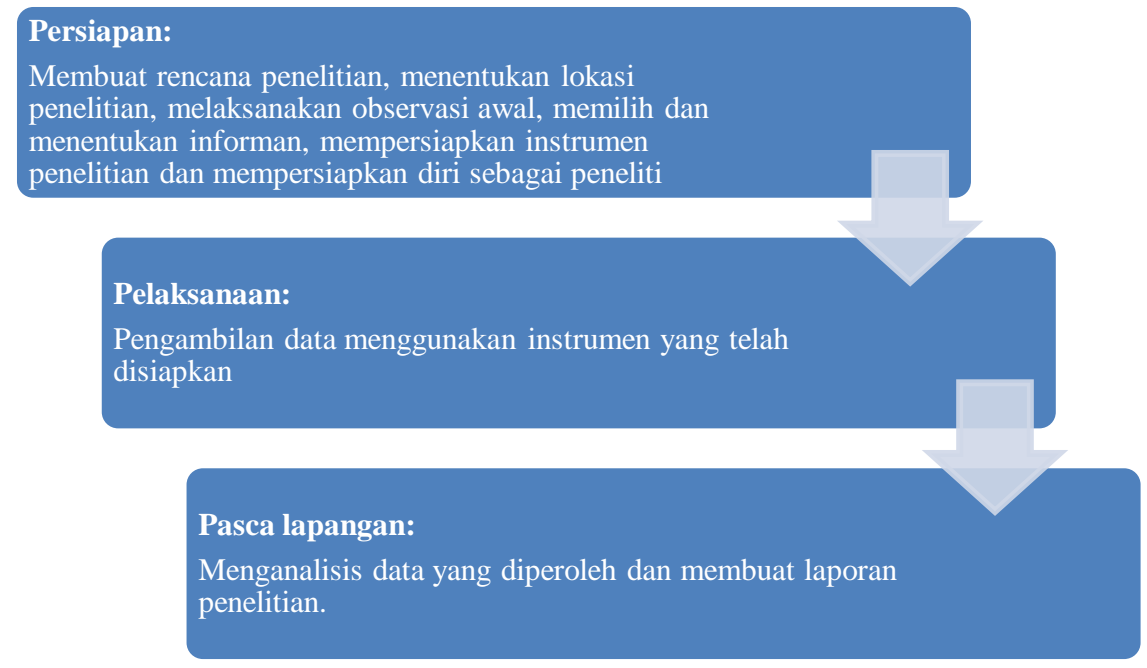

Gambar 1. Alur Penelitian

\section{HASIL DAN DISKUSI}

Penelitian ini dilakukan di daerah Kabupaten Majalengka dengan teknik wawancara semi terstruktur kepada lima siswa kelas IV SD di daerah Kabupaten Majalengka. Narasumber yang diwawancarai secara pribadi yaitu, AL, R, RNB, SL, dan T. Wawancara dilakukan pada hari selasa, 8 Desember 2020. Narasumber dengan inisial SL pada pukul 12.35, narasumber dengan inisial AL pada pukul 13.00, narasumber dengan inisial $\mathrm{T}$ pada pukul 13.11, narasumber dengan inisial $\mathrm{R}$ pada pukul 13.20, sedangkan narasumber dengan inisial RNB pada pukul 13.27. Berikut dokumentasi kegiatan wawancara yang dilakukan terhadap siswa disajikan pada Gambar 2 dan Gambar 3 berikut. 


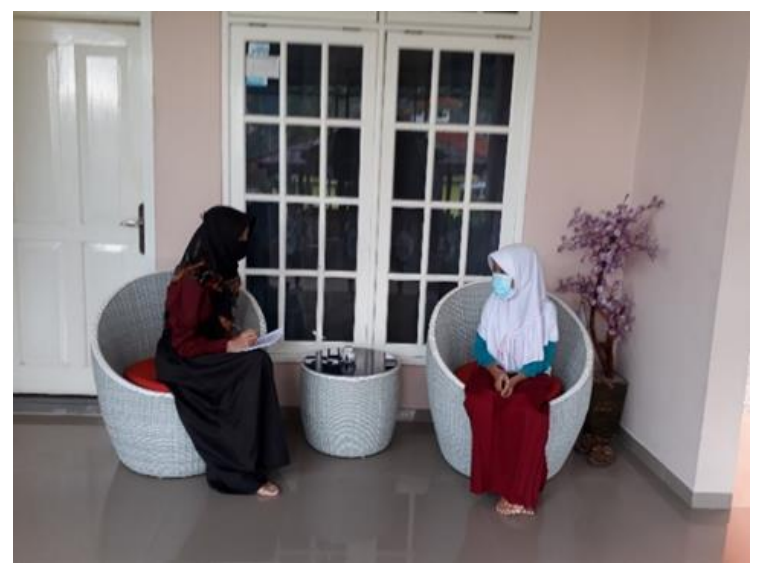

Gambar 2: Kegiatan wawancara dengan narasumber SL

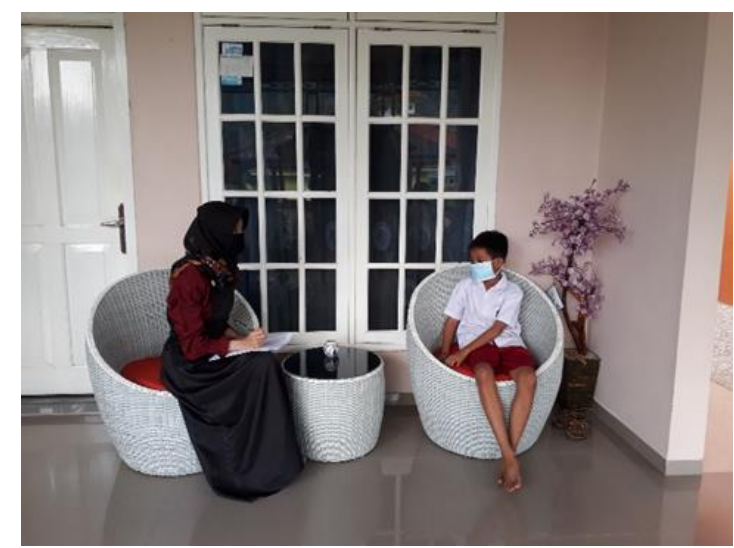

Gambar 3. Kegiatan wawancara dengan narasumber AL

Wawancara ini dilakukan berdasarkan indikator kesulitan belajar siswa pada pembelajaran daring matematika di masa pandemi (Utami, Y. P., \& Cahyono, 2020).

\section{Kendala Teknis Yang Mempengaruhi Signal dan Ketidakmampuan dalam Pembelajaran Online}

Berdasarkan hasil wawancara kepada lima siswa kelas IV, hanya R dan RNB yang berpendapat bahwa pembelajaran berbasis daring khususnya pada pelajaran matematika mudah dilaksanakan. Sedangkan ketiga siswa lainnya berpendapat bahwa pembelajaran berbasis daring khususnya pada pelajaran matematika sulit dilaksanakan. Aplikasi yang digunakan selama pembelajaran daring khususnya pada pelajaran matematika menurut kelima siswa adalah aplikasi WhatsApp. Kelima siswa menutukan bahwa mereka tidak mengalami kesulitan dalam menggunakan aplikasi tersebut. Selanjutnya, terkait hambatan dalam pelaksanaan pembelajaran daring khususnya dalam pembelajaran matematika, hanya R yang tidak mempunyai hambatan. Sedangkan AL, RNB, SL dan T mempunyai beberapa hambatan yang di antaranya adalah sinyal, kuota, dan materi pelajaran matematikanya sendiri. Melakukan pembelajaran, membaginya melalui interaksi, tugas dan bahan ajar dalam pembelajaran online

Dari kelima siswa, hanya T saja yang tidak meyukai pelajaran matematika. Sedangkan keempat lainnya menyukai pelajaran matematika. A, RNB, dan SL mengatakan bahwa mereka kurang menyukai guru yang mengajar pelajaran matematika. Sedangkan R dan T menyukai guru tersebut. Kelima siswa 
Kesulitan Belajar Siswa pada Pembelajaran Daring Matematika di Masa Pandemi, Ervika Ratna Yulia, Ika Wahyuni, Anggita Maharani

menuturkan bahwa mereka hanya akan belajar matematika pada saat jam pelajarannya saja. Hal tersebut menunjukkan rendahnya motivasi belajar siswa, hal ini sejalan dengan penelitian (Nasrah \& Muafiah, 2020; Yusuf Al-Amin, 2021) (Nasrah \& Muafiah, 2020)bahwa perlunya meningkatkan motivasi siswa dalam pembelajaran daring.

Menurut jawaban yang dituturkan siswa, dalam pembelajaran di sekolah khususnya dalam pelajaran matematika, guru selalu membuka sesi tanya jawab dan diskusi dengan siswa. Namun, dalam pembelajaran berbasis daring khususnya dalam pelajaran matematika, guru tidak membuka sesi tanya jawab dan diskusi. Mereka pun menuturkan bahwa cara mengajar guru matematika dalam pembelajaran berbasis daring tidaklah menyenangkan, sehingga tidak membuat mereka paham dengan materi yang diajarkan.

Dalam pembelajaran berbasis daring khususnya dalam pelajaran matematika, kelima siswa menuturkan bahwa gurunya selalu memberikan tugas, dan tugas yang diberikan tersebut tidaklah sedikit. Bahkan, empat siswa yang diwawancara menganggap tugas-tugas yang diberikan tergolong sulit. Hanya R saja yang menganggapnya tidak sulit. Dengan pemberian tugas tersebut, empat siswa merasa menjadi semakin paham dengan materi pelajaran matematika yang diajarkan. Sedangkan A merasa biasa saja. Menurutnya pemberian PR tidak berdampak apa-apa.

Kelima siswa menuturkan, ketika belajar di sekolah guru menggunakan alat peraga. Alat peraga yang pernah digunakan selama belajar di sekolah salah satunya adalah kubus. Mereka menuturkan bahwa dengan digunakannya alat peraga dalam proses pembelajaran membuat mereka semakin paham dengan materi yang diajarkan. Sayangnya, dalam pembelajaran daring kelima siswa menuturkan bahwa guru tidak pernah menggunakan alat peraga. Guru hanya mengirim materi melalui wa, kemudian memberikan tugas.

Terkait sumber belajar, kelima siswa menuturkan bahkan sumber belajar yang mereka gunakan adalah buku paket yang difasilitasi oleh sekolah. Sumber belajar lainnya adalah materi pelajaran yang mereka dapatkan dari internet. Salah satu sumber belajar yang juga digunakan oleh kelima siswa adalah brainly. Mereka menuturkan bahwa dengan digunakannya sumber belajar memang membuat mereka menjadi lebih paham dengan materi yang diajarkan. Namun, mereka pun menuturkan bahwa mereka akan lebih paham lagi dengan materi yang diajarkan jika mendapatkan penjelasan secara langsung dari guru pelajaran.

\section{Stakeholder Yang Membantu Pemerintah, Sekolah dan Wali Murid dalam Pembelajaran Online}

Kelima siswa menuturkan bahwa mereka mendapatkan tunjangan kuota yang diterima dari pemerintah untuk pembelajaran berbasis daring di rumah, yang khususnya mereka gunakan pada pelajaran matematika. Kemudian, kelimanya pun menuturkan bahwa sekolah hanya memberikan masker saja di awal adanya pandemi. Sedangkan, fasilitas yang disiapkan oleh orang tua untuk menunjang pembelajaran daring di rumah khususnya pada pelajaran matematika adalah HP dan kuota. Kelima siswa pun menuturkan bahwa tidak ada lagi pihak lain yang memberikan bantuan yang mendukung pelaksanaan pembelajaran daring di rumah khususnya pada pelajaran matematika. 
Secara garis besar ada dua jenis kesulitan dalam pembelajaran online, yakni kesulitan pemahaman konsep terkait materi matematika dan kesulitan kendala teknis, hal ini sejalan dengan penelitian yang dilakukan (Anugrahana, 2021). Dalam penelitian (Simanjuntak \& Harahap, 2020; Turmuzi et al., 2021; Utami, Y.P., \& Cahyono, 2020) mengungkap bahwa kendala terbesar dalam pembelajaran online adalah teknis signal dan ketidakmampuan dalam belajar online. Hal ini diperkuat oleh penelitian (Jamaluddin et al., 2020) kendala tersebut berpengaruh terhadap kondisi psikis siswa seperti kecemasan siswa. Upaya yang dilakukan untuk mengatasi kecemasan diantaranya belajar mandiri, menyelesaikan tugas tanpa menundanya, berdiskusi dengan teman atau guru, berdoa, menyemangati diri sendiri, serta melakukan aktivitas lain seperti menonton film, mendengarkan musik, istirahat yang cukup, makan, dan olahraga (Oktawirawan, 2020).

Selama pembelajaran daring siswa tidak terbiasa belajar secara mandiri sehingga dalam memahami konsep materi mengalami kesulitan, apalagi jika tidak mendapat pendampingan dari orang tua. Kesulitan tersebut diantaranya terbatasnya interaksi dengan guru, banyaknya rumus yang digunakan dan objek yang di pelajari dalam matematika bersifat abstrak (Fauzy \& Nurfauziah, 2021). Sedangkan dalam penelitiannya menemukan kesulitan belajar matematika diantaranya kesulitan memahami konsep, kesulitan memecahkan masalah dan kesulitan dalam keterampilan berhitung. Oleh karena itu membutuhkan kreatifitas dari guru dalam menggunakan model pembelajaran yang sesuai. Selain itu perlu berstrategi dalam menerapkan pembelajaran daring dengan memandang kesulitas sebagai tantangan pembelajaran sebagai upaya menciptakan pembelajaran yang lebih baik dan bermakna (Oktiutami, Vera and Syahrial, Syahrial and Sofwan, 2020).

Selain banyak kesulitan ternyata ada kelebihan pembelajaran online/daring, seperti siswa dapat mengakses materi secara berulang ulang artinya memudahkan akses siswa dalam mempelajari materi yang diberikan serta dapat bertukar informasi dengan siswa yang lain, hal ini sejalan dengan penelitian yang dilakukan (Yulia \& Putra, 2020).

\section{KESIMPULAN}

Berdasarkan hasil wawancara kepada lima orang siswa kelas IV SD Negeri di Desa Lengkong Wetan, Kecamatan Sindangwangi, Kabupaten Majalengka menurut indikator yang telah diuraikan diatas dapat disimpulkan bahwa kesulitan belajar yang dialami siswa pada pembelajaran daring matematika di masa pandemi di antaranya 1) Menurut indikator yang pertama yaitu kendala teknis yang mempengaruhi signal dan ketidakmampuan dalam pembelajaran online adalah kendala pada sinyal dan kuota yang dimiliki. 2) Menurut indikator yang kedua yaitu melakukan pembelajaran, membaginya melalui interaksi, tugas dan bahan ajar dalam pembelajaran online, karena siswa tidak menyukai mata pelajaran matematika, tidak menyukai guru yang mengajar mata pelajaran matematika, siswa hanya belajar matematika pada saat jam pelajarannya saja, dalam pembelajaran daring matematika guru yang mengajar tidak membuka sesi tanya jawab dengan siswa, cara mengajar guru dalam pembelajaran matematika berbasis daring pun dianggap tidak menyenangkan sehingga tidak membuat siswa semakin 
Kesulitan Belajar Siswa pada Pembelajaran Daring Matematika di Masa Pandemi, Ervika Ratna Yulia, Ika Wahyuni,

paham dengan materi pelajaran matematika yang diajarkan, tugas-tugas yang diberikan juga cukup banyak dan cenderung sulit, serta guru tidak menggunakan alat peraga seperti ketika pembelajaran di dalam kelas. 3) Menurut indikator yang ketiga yaitu stake holder yang membantu pemerintah, sekolah dan wali murid dalam pembelajaran online adalah tidak adanya stake holder yang membantu membantu pemerintah, sekolah dan wali murid dalam pembelajaran online.

Untuk mengatasi permasalahan kesulitan belajar tersebut diharapkan adanya dukungan dan kerjasama antara orang tua, sekolah/guru dan juga stake holder sehingga pembelajaran bisa berjalan dengan baik. Dalam hal ini guru dituntut kreatifitasnya untuk melaksanakan pembelajaran yang dapat memotivasi belajar siswa agar lebih baik lagi. Selain itu perlu ditingkatkannya pemanfaatan teknologi informasi dalam pembelajaran.

\section{REFERENSI}

Anugrahana, A. (2021). Analisis Kemampuan Pemahaman Kognitif Dan Kesulitan Belajar Matematika Konsep "Logika" Dengan Model Pembelajaran Daring. Scholaria: Jurnal Pendidikan Dan Kebudayaan, 11(1), 37-46. https://doi.org/10.24246/j.js.2021.v11.i1.p37-46

Ari, I. N., \& Sihombing, Y. (2017). Deskripsi Kesulitan Belajar Peserta Didik dan Faktor Penyebabnya dalam Memahami Materi Listrik Dinamis Kelas X SMA Negeri 2 Bengkayang. Jurnal Penelitian Fisika Dan Aplikasinya, Vol.7 No.1, 44-53.

Fauzy, A., \& Nurfauziah, P. (2021). Kesulitan Pembelajaran Daring Matematika Pada Masa Pandemi COVID-19 di SMP Muslimin Cililin. Jurnal Cendekia : Jurnal Pendidikan Matematika, 5(1), 551-561. https://doi.org/10.31004/cendekia.v5i1.514

Gumilang, G. S. (2016). Metode Penelitian Kualitatif dalam Bidang Bimbingan dan Konseling. Jurnal Fokus Konseling. Jurnal Fokus Konseling, Vol.2 No.2, 144-159.

Handayani, D., Hadi, R, D., Isbaniah, F., Burhan, E., \& Agustin, H. (2020). Penyakit Virus Corona 2019. Jurnal Respirologi Indonesia, Vol.40 No., 119-129.

Ilpaj, S. M., \& Nurwati, N. (2020). Analisis Pengaruh Tingkat Kematian Akibat COVID-19 terhadap Kesehatan Mental Masyarakat di Indonesia. Jurnal Pekerjaan Sosial, Vol.3 No.1, 16-28.

Ismail. (2016). Diagnosis Kesulitan Belajar Siswa Dalam Pembelajaran Aktif di Sekolah. Jurnal Edukasi, Vol.2 No.1, 30-43.

Jamaluddin, D., Ratnasih, T., Gunawan, H., \& Paujiah, E. (2020). Pembelajaran Daring Masa Pandemik Covid-19 Pada Calon Guru: Hambatan, Solusi dan Proyeksi. Karya Tulis Ilmiah UIN Sunan Gunung Djjati Bandung, 1-10. http://digilib.uinsgd.ac.id/30518/

Januarti, N. K., Dibia, I. K., \& Widiana, I. W. (2016). Analisis Kesulitan Belajar dalam Pembelajaran Membaca Cepat Siswa Kelas V SD Gugus VI Kecamatan Abang. E-Journal PGSD Universitas Pendidikan Ganesha, 4(1), 1-10.

Mutia. (2019). Analisis Kesulitan Belajar Matematika Siswa SMP Kelas IX dalam Memahami Konsep Tabung dan Alternatif Pemecahannya dengan Pendekatan Pemecahan Masalah. Jurnal Equation, 
Vol.2 No.1, 1-21.

Nasrah, \& Muafiah, A. (2020). Analisis Motivasi Belajar Dan Hasil Belajar Daring Mahasiswa Pada Masa Pandemik Covid-19. Jurnal Riset Pendidikan Dasar, 2(oktober), 207-213.

Oktawirawan, D. H. (2020). Faktor Pemicu Kecemasan Siswa dalam Melakukan Pembelajaran Daring di Masa Pandemi Covid-19. Jurnal Ilmiah Universitas Batanghari Jambi, 20(2), 541. https://doi.org/10.33087/jiubj.v20i2.932

Oktiutami, Vera and Syahrial, Syahrial and Sofwan, M. (2020). Strategi guru mengatasi kesulitan belajar pada pembelajaran daring kelas V sekolah dasar YKPP bajubang. Universitas Jambi.

Rachmawati, I. N. (2007). Pengumpulan Data dalam Penelitian Kualitatif: Wawancara. Jurnal Keperawatan Indonesia, Vol.11 No., 35-40.

Raco, Dr. J. R., M.E, M. S. (2004). Metode Penelitian Kualitatif Jenis, Karakteristik dan Keunggulannya. PT Gramedia Widiasarana Indonesia.

Simanjuntak, D. R., \& Harahap, M. S. (2020). Pembelajaran Secara Daring Selama Masa Pandemi Covid-19. JURNAL MathEdu (Mathematic Education Journal), 3(3), 142-146. http://journal.ipts.ac.id/index.php/MathEdu

Turmuzi, M., Dasing, A. S. H., Baidowi, \& Junaidi. (2021). Analisis Kesulitan Belajar Mahasiswa Secara Online (E-Learning) Selama Masa Pandemi Covid-19. Edukatif: Jurnal Ilmu Pendidikan, 3(3), 900-910.

Utami, Y. P., \& Cahyono, D. A. D. (2020). Study at Home: Analisis Kesulitan Belajar Matematika pada Proses Pembelajaran Daring. Jurnal Ilmiah Matematika Realistik, Vol.1 No.1, 20-26.

Yulia, I. B., \& Putra, A. (2020). Kesulitan Siswa Dalam Pembelajaran Matematika Secara Daring. Refleksi Pembelajaran Inovatif, Vol. 2, No. 2, 2020, 2(2), 327-335.

Yusuf Al-Amin, B. M. (2021). Analisis Kesulitan Belajar Matematika pada Proses Pembelajaran Daring Menggunakan Metode Pembelajaran Berbasis Masalah. Jurnal Penelitian Didaktik Matematika, Vol 5. 